\title{
Patterns of echinoid bioerosion in two Pacific coral reef lagoons
}

\author{
R. P. M. Bak \\ Netherlands Institute for Sea Research (NIOZ), PO Box 59, 1790 AB Den Burg, Texel, The Netherlands \\ and \\ Centre de l'Environnement d'Opunohu, MNHN-EPHE, Moorea, Polynesie Francaise
}

\begin{abstract}
Echinoid populations can be major grazers on hard reef substrata and are consequently of importance in the bioerosion of coral reefs. There are no previous data on rates or patterns of bioerosion by the echinoid community in Indo-Pacific reefs. We surveyed densities of echinoid populations in 2 reef lagoons, the Tiahura section, northwest Moorea (Society Islands) and the central lagoon of Takapoto atoll (Tuamotu Islands), and determined echinoid erosion rate of the reef structure. Echinometra mathaei was the most numerous urchin in Tiahura $\left(7.4 \mathrm{~m}^{-2}\right)$ followed by Diadema savignyi $\left(4.8 \mathrm{~m}^{-2}\right)$, Echinothrix diadema $\left(0.6 \mathrm{~m}^{-2}\right)$ and Echinostrephus molaris $\left(0.2 \mathrm{~m}^{-2}\right)$. E. mathaei and E. molaris are small urchins processing small amounts of carbonate rock and the impact of their populations as bioeroders is limited at such densities, even for the numerous E. mathaei $\left(1.0 \mathrm{~g} \mathrm{~m}^{-2} \mathrm{~d}^{-1}\right)$. D. savignyi and E. diadema are large (mode test diameter 55 and $60 \mathrm{~mm}$ respectively) and their populations consumed 9.2 and $2.2 \mathrm{~g} \mathrm{~m}^{-2} \mathrm{~d}^{-1}$ of hard substratum respectively. In Takapoto lagoon, the same species were present (except E. molaris), but densities of urchins were extremely low and echinoid bioerosion was only of importance close to lagoonal inlets $\left(6.2 \mathrm{~g} \mathrm{~m}^{-2} \mathrm{~d}^{-1}\right)$. In situ growth of the hard reef substratum in Moorea is predominantly through growth of massive Porites colonies and estimated at $6 \mathrm{~g} \mathrm{~m}^{-2} \mathrm{~d}^{-1}$. The conclusion is that, with an echinoid bioerosion rate of $12.5 \mathrm{~g} \mathrm{~m}^{-2} \mathrm{~d}^{-1}$ the reef structure is being destroyed. The observed urchin densities are high for oceanic islands of the Indo-Pacific region and the possibility of a relation between human influence on the reef and urchin densities should be considered.
\end{abstract}

\section{INTRODUCTION}

The magnitude of constructive and destructive forces is a deciding factor in the fate of coral reefs. Echinoids can be major grazers on hard reef substrata (Hawkins \& Lewis 1982) and as such they are important in the bioerosion of reefs. They may process as much as $9.7 \mathrm{~kg}$ carbonate $\mathrm{m}^{-2} \mathrm{yr}^{-1}$ (Hunter 1977) and be responsible for $80 \%$ of the total erosion of reefs (Scoffin et al. 1980). On some reefs their position has been shown to be crucial in the balance between the construction and destruction of the reef structure (Scoffin et al. 1980, Bak et al. 1984).

Such data are apparently restricted to Atlantic reefs and marginal reefs in the Pacific such as in the Galapagos Islands (Glynn et al. 1979). The data available on urchin population densities in the Indo-Pacific show a highly variable pattern with occasional high densities restricted to the continental-shelf Indo-Pacific (Birkeland 1989). In many areas (e.g. Oceania, the Great Barrier Reef) echinoids are considered not to be very prominent and echinoid bioerosion seems to be much less significant (Ogden 1987, Sammarco 1987, Bak \& Povel 1989).

It appears that in some habitats on French Polynesia reefs echinoderms, such as Diadema and Echinothrix species, can be conspicuous members of the benthos. This report presents results of a survey recording echinoid densities in different microhabitats in 2 lagoons and a short investigation of their possible impact as bioeroders on the reef structure.

\section{MATERIAL AND METHODS}

Densities of echinoid populations were recorded during October 1987 in 2 lagoons, the Tiahura section, northwest Moorea (Society Islands) and the central lagoon of Takapoto atoll (Tuamoto Islands; Fig. 1). For logistic reasons access to the reefs was limited to the daytime when urchins avoided open space and kept to crevices in and under coral heads. 


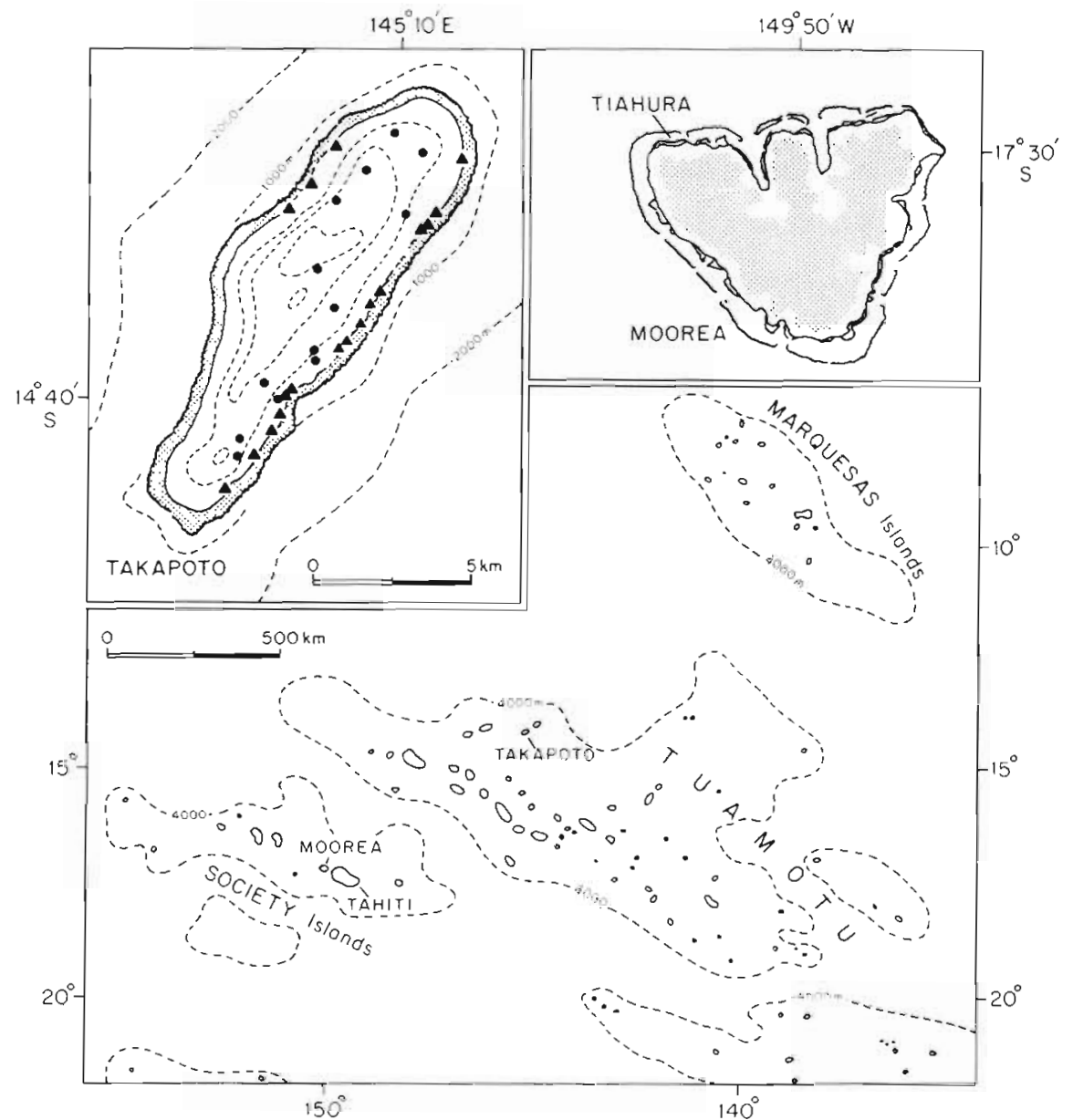

Fig. 1. Location of Moorea in the Society Islands and Takapoto in the Tuamotus, Inset of Moorea shows the Tiahura reef section. Inset of Takapoto shows position of surveyed pinnacles $(\bullet)$ and patch reefs $(\bullet)$
On Tiahura the study site (depth 1.5 to $2.5 \mathrm{~m}$, section 8 in Fig. 5, Galzin \& Pointer 1985) was dominated by isolated colonies of massive Porites, living or dead at different stages of destruction, separated by sand/rubble stretches. We used ten $10 \mathrm{~m}$ long line transects to assess cover of sand, rubble, dead and living coral colonies. Subsequently, we concentrated our efforts on diligently extracting all urchins in beit transects $150 \mathrm{~cm}$ wide, total length $34 \mathrm{~m}$ ) over living and dead colonies. All urchin maximum test diameters were measured (mm). Condition of coral colonies and cover of living tissue were recorded in the $50 \times 50 \mathrm{~cm}$ quadrats of the belt transects. From these 2 sets of data, viz. urchin density/substratum and cover of substratum, urchin densities were calculated for the area.

To assess the quantity of carbonate eroded from the reef framework by Diadema savignyi Michelin, Echinothrix diadema (Linnaeus) and Echinometra mathaei (de Blainville), a range of differently sized individuals $(\mathrm{n}=11)$ of each species were collected separately outside the transects and the gut content (ash-free dry weight) of each specimen was determined. This is a measure of the minimum consumption over a 24 h period (Glynn et al. 1979, Hawkins \& Lewis 1982). E. mathaei lives within the close vicinity of its burrows but $D$. savignyi and E. diadema graze over larger areas. The source of consumed carbonate (hard substratum or loose sediment) is reflected in the composition of urchin faecal pellets (Hunter 1977. Scoffin et al. 1980). We identified and counted at least 200 pellets of each species in thin section. To prepare petrographic sections, $D$. savignyi and $E$. diadema pellets were slowly dried $\left(35^{\circ} \mathrm{C}\right)$ and impregnated with epoxy resin (HY 951/103, Geigy, Bazel). Pellets of the same diameter were mounted on glass (epoxy glue, Frencken, Weerd) and cut to a thickness of $25 \mu \mathrm{m}$.

Gut contents are known to vary quantitatively as well as qualitatively with urchin size (e.g. Scoffin et al. 1980). We used the significant exponential relationships between test size and gut content $(D$. savignyi $\mathrm{r}=$ 0.966 , E. diadema $\mathrm{r}=0.871$, E. mathaei $\mathrm{r}=0.860$, all $\mathrm{p}$ $<0.01$ ) to calculate the carbonate consumption for the different sizes classes. The size/frequency data recorded in the belt transects were used to obtain the mean consumption of the populations. Faecal pellets were collected in the field from random individuals. 

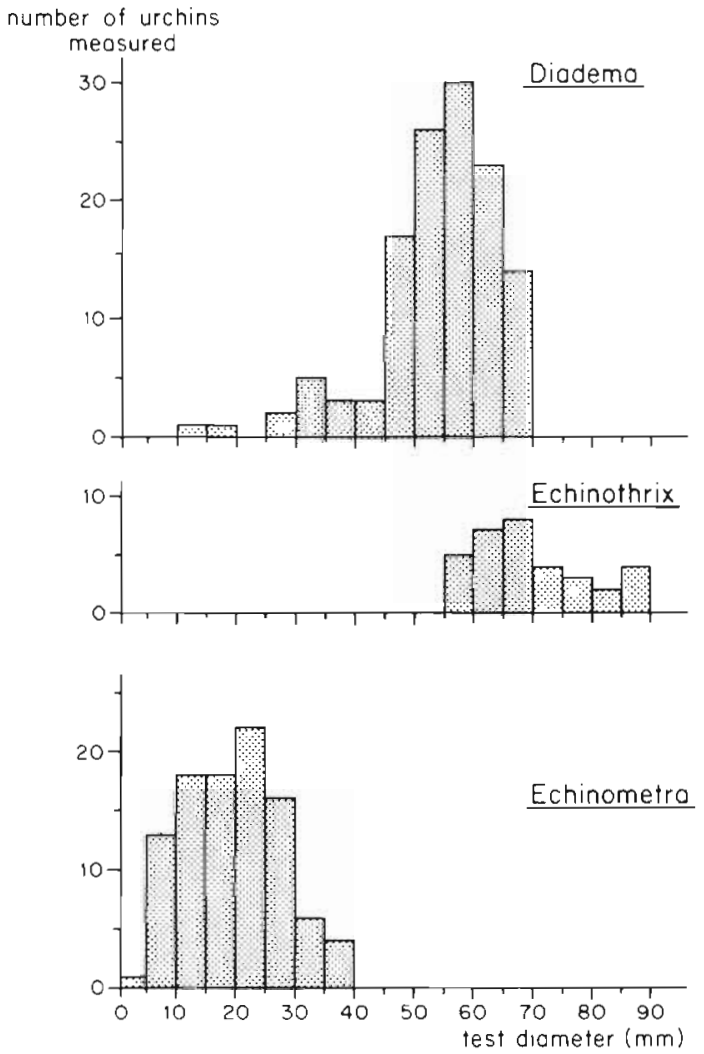

Fig. 2. Size distributions at Tiahura of Diadema savignyi $(\mathrm{n}=$ 126), Echinothrix diadema $(\mathrm{n}=34)$, and Echinometra mathaei ( $\mathrm{n}=99$ )

The distribution pattern of echinoids denied a similar approach in Takapoto lagoon. Two distinct reefal habitats exist in the lagoon: isolated pinnacle reefs occur throughout, rising from deeper water (10 to $40 \mathrm{~m})$ to near the surface, while small patch reefs are found shallow along the lagoonal border. We visited 13 pinnacles and 18 patch reefs to check for the presence of urchins. Whenever urchins were present their densities and cover of substratum components were recorded in $10 \times 0.5 \mathrm{~m}$ wide belt transects

\section{RESULTS}

Of the 4 urchin species present in the Tiahuara transect [Diadema savignyi, Echinometra mathaei, Echinothrix diadema and Echinostrephus molaris (de Blainville)], the first two occurred in high densities. $D$. savignyi and E. diadema were found on the same substratum while E. mathaei and E. molaris showed preference for other specific microhabitats.

Diadema savignyi reached mean densities of $14.1 \mathrm{~m}^{-2}$ on dead/partially dead coral colonies but was absent on the remains of totally eroded colonies.
Echinothrix diadema showed the same distribution pattern at much lower densities $\left(1.8 \mathrm{~m}^{-2}\right)$. Highest Echinometra mathaei densities occurred on dead colonies $\left(38.4 \mathrm{~m}^{-2}\right)$ but E. mathaei was, in contrast to the former species, also common on the totally eroded flat remains of colonies $\left(7.7 \mathrm{~m}^{-2}\right)$. Echinostrephus molaris occurred only on these totally eroded remains $\left(1.7 \mathrm{~m}^{-2}\right)$. All species were uncommon on living coral colonies. Size distributions for all species (except the uncommon E. molaris) are shown in Fig. 2 and population densities in Table 1.

There were large differences in the quantities of carbonate in the guts of the various species. Echinometra matthaei is small (dissected specimens 16 to $32 \mathrm{~mm}, \overline{\mathrm{x}}=24 \mathrm{~mm}$ ) and gut content weight was low $(\bar{x}=0.18 \mathrm{~g})$. Diadema Savignyi and especially Echinothrix diadema are very large with test size among dissected specimens up to 69 and $88 \mathrm{~mm}$, respectively. Mean carbonate content of the gut was $5.2 \mathrm{~g}$ for $D$. savignyi and $7.4 \mathrm{~g}$ for $E$. diadema.

The composition of the faecal pellets indicated a hard substratum origin for the majority of the carbonate particles. In Diadema savignyi the ratio hard substratum/loose sediment was 67 to $33 \%$, in Echinothrix diadema 52 to $48 \%$. Combining the data on cover of bottom components, urchin population densities and size frequencies, gut content/urchin size class and origin of gut carbonate, total bioerosion for each species can be calculated. D. savignyi is a very common and large urchin, and the bulk of the daily reef frame

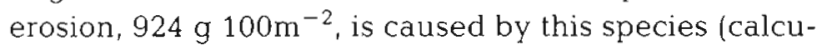
lation shown in Table 2). E. diadema is large but much less numerous (Table 1 ) and a similar calculation

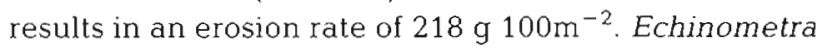
mathaei is numerous but small, gut content weight is low and total bioerosion of this urchin amounts only to

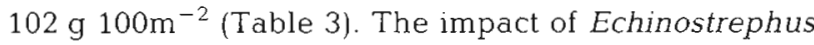
molaris, a rare species in the area, can be ignored. Consequently, the total erosion of the reef framework

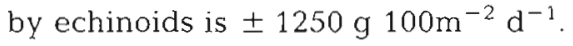

In Takapoto a very different pattern emerged. The most thorough searching did not reveal a single urchin on the pinnacles. Also coral patches along the lagoonal border proved to be devoid of echinoids, except when the patches were in the vicinity, or in the entrance, of a Hoa (shallow lagoonal inlet). However, transect surveys $(n=6)$ showed urchins to be present at low densities: Diadema savignyi $0.3 \mathrm{~m}^{-2}$, Echinothrix diadema $0.9 \mathrm{~m}^{-2}$ and Echinometra mathaei $0.4 \mathrm{~m}^{-2}$. Assuming the species-specific rates of reef framework erosion to be similar in Takapoto and Moorea, D. savig-

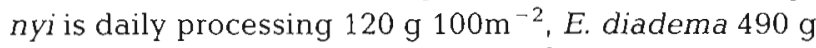
$100 \mathrm{~m}^{-2}$ and $E$. mathaei $8 \mathrm{~g} 100 \mathrm{~m}^{-2}$. Total hard substratum erosion in this spacially restricted habitat

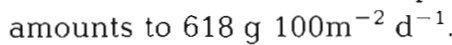


Table 1. Urchin densities per substratum component during daytime per $100 \mathrm{~m}^{2}$ reef bottom at Tiahura

\begin{tabular}{|c|c|c|c|c|c|}
\hline Bottom components & $\begin{array}{c}\% \text { Cover of } \\
\text { bottom component }\end{array}$ & $\begin{array}{l}\text { Diadema } \\
\text { savignyi }\end{array}$ & $\begin{array}{c}\text { Echinothrix } \\
\text { diadema }\end{array}$ & $\begin{array}{c}\text { Echinometra } \\
\text { mathaei }\end{array}$ & $\begin{array}{c}\text { Echinostrephus } \\
\text { molaris }\end{array}$ \\
\hline Coral (living surface $50-100 \%$ ) & 4.5 & 3 & 7 & 2 & 0 \\
\hline Coral (living surface 5-50\%) & 25.5 & 360 & 33 & 187 & 0 \\
\hline Coral (living surface $<5 \%$ ) & 12.5 & 121 & 22 & 480 & 0 \\
\hline Flat, eroded coral surfaces & 9.0 & 0 & 3 & 69 & 15 \\
\hline Rubble and sediment & 24.0 & 0 & 0 & 0 & 0 \\
\hline Fine sediment & 24.5 & 0 & 0 & 0 & 0 \\
\hline Total urchin densities $\left(100 \mathrm{~m}^{-2}\right)$ & & 484 & 65 & 738 & 15 \\
\hline
\end{tabular}

Table 2. Diadema savignyi. Daily reef-framework erosion $\left(\mathrm{g} 100 \mathrm{~m}^{-2}\right)$ at Tiahura reef

\begin{tabular}{|c|c|c|c|c|}
\hline $\begin{array}{l}\text { Size class }^{\mathrm{a}} \\
\quad(\mathrm{mm})\end{array}$ & $\begin{array}{l}\text { Urchin density } \\
\qquad\left(100 \mathrm{~m}^{-2}\right)\end{array}$ & $\begin{array}{c}\text { Gut content } \\
\left\{\mathrm{g} \mathrm{CaCO}_{3} \text { urchin }^{-1}\right)\end{array}$ & $\begin{array}{l}\text { Daily content } \\
\text { of size class }\end{array}$ & Daily erosion ${ }^{b}$ \\
\hline $10-14$ & 4 & 0.01 & 0.04 & 0.03 \\
\hline $15-19$ & 4 & 0.01 & 0.04 & 0.03 \\
\hline $20-24$ & - & - & - & - \\
\hline $25-29$ & 8 & 0.04 & 0.32 & 0.21 \\
\hline $30-34$ & 19 & 0.16 & 3.04 & 2.04 \\
\hline $35-39$ & 12 & 0.36 & 4.32 & 2.89 \\
\hline $40-44$ & 12 & 0.71 & 8.52 & 5.71 \\
\hline $45-49$ & 66 & 1.06 & 69.96 & 46.87 \\
\hline $50-54$ & 101 & 1.87 & 188.87 & 126.54 \\
\hline $55-59$ & 116 & 3.03 & 351.48 & 235.49 \\
\hline $60-64$ & 89 & 4.32 & 384.48 & 257.60 \\
\hline $65-69$ & 54 & 6.81 & 367.74 & 246.39 \\
\hline \multicolumn{2}{|c|}{ Total daily erosion $\left(\mathrm{g} 100 \mathrm{~m}^{-2}\right)$} & & & 924 \\
\hline
\end{tabular}

Table 3. Echinometra mathaei. Daily reef-framework erosion (g $\left.100 \mathrm{~m}^{-2}\right)$ at Tiahura reef

\begin{tabular}{|c|c|c|c|c|}
\hline $\begin{array}{l}\text { Size class }^{a} \\
\quad(\mathrm{~mm})\end{array}$ & $\begin{array}{l}\text { Urchin density } \\
\left(100 \mathrm{~m}^{-2}\right)\end{array}$ & $\begin{array}{c}\text { Gut content } \\
\left(\mathrm{g} \mathrm{CaCO}_{3} \text { urchin }^{-1}\right)\end{array}$ & $\begin{array}{l}\text { Daily content } \\
\text { of size class }\end{array}$ & Daily erosion \\
\hline $0-4$ & 8 & 0.00 & 0.02 & 0.02 \\
\hline $5-9$ & 98 & 0.02 & 1.96 & 1.96 \\
\hline $10-14$ & 136 & 0.05 & 6.80 & 6.80 \\
\hline $15-19$ & 136 & 0.10 & 13.60 & 13.60 \\
\hline $20-24$ & 166 & 0.16 & 26.56 & 26.56 \\
\hline $25-29$ & 121 & 0.23 & 27.83 & 27.83 \\
\hline $30-34$ & 45 & 0.31 & 13.95 & 13.95 \\
\hline $35-39$ & 30 & 0.40 & 12.00 & 12.00 \\
\hline \multicolumn{2}{|c|}{ Total daily erosion $\left(\mathrm{g} 100 \mathrm{~m}^{-2}\right)$} & & & 102 \\
\hline
\end{tabular}

\section{DISCUSSION}

There are hardly any data available on bioerosion rates in these Indo-Pacific echinoid species. Nothing is known for Diadema savignyi and Echinothrix diadema.
Comparable to $D$. savignyi is the Atlantic species $D$. antillarum. Erosion rates are reported to vary from 0.6 to $1.4 \mathrm{~g} \mathrm{urchin}^{-1} \mathrm{~d}^{-1}$ for this species in the Caribbean (Hunter 1977. Ogden 1977, Scoffin et al. 1980). The Pacific diadematids studied processed appreciably 


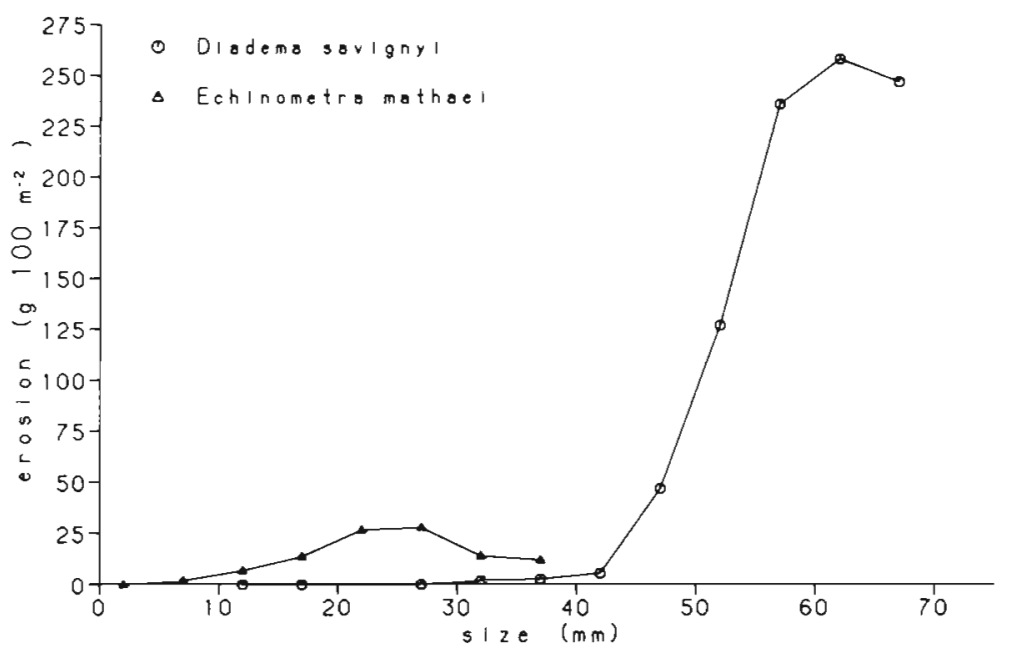

Fig. 3. Diadema savignyi and Echinometra mathaei. Daily reef-framework erosion for urchins of different size classes higher amounts of carbonate rock, with means of 1.9 and $3.3 \mathrm{~g} \mathrm{urchin}^{-1} \mathrm{~d}^{-1}$ respectively for $D$. savignyi and $E$. diadema. The reason appears to be that the amount of erosion per urchin is strongly related to size (Fig. 3). Our urchins were large, close to their maximum size (Ebert 1975, 1982), while mean size for Caribbean Diadema populations is generally smaller (e.g. Scoffin et al. 1980).

Echinometra mathaei is a modest bioeroder. Erosion rates reported for Enewetak and Hawaii (Russo 1980). $0.11 \mathrm{~g} \mathrm{urchin}^{-1} \mathrm{~d}^{-1}$, are close to our mean $0.14 \mathrm{~g}$ urchin $^{-1} \mathrm{~d}^{-1}$. Higher rates, e.g. 0.9 to $1.4 \mathrm{~g}$ (Arabian Gulf; Downing \& El-Zahr 1987), can also be related to differences in size of mean test diameters of experimental individuals (means of 19.5, 19.3 and 37.1, respectively for erosion rates cited). Birkeland (1989) points out the importance of different patterns of behaviour in this urchin.

Actual echinoid erosion rate of the reef structure depends, apart from species-specific erosion rates and size distribution, on population densities. Densities of echinoids are high on Moorea compared with some other Indo-Pacific reefs (e.g. Guam, Belau: Birkeland 1984; Great Barrier Reef: Sammarco 1987; Indonesia: Bak \& Povel 1989, de Beer pers. comm.) and total echinoid bioerosion, $12.5 \mathrm{~g} \mathrm{~m}^{-2} \mathrm{~d}^{-1}$, must be high for the region. There are, however, no comparable data available for this region.

In the Caribbean, Diadema antillarum was an abundant reef urchin before mass mortalities (e.g. Lessios et al. 1984) made it rare. At high densities, 9 to 23 urchins $\mathrm{m}^{-2}$, erosion rates varied from 8 to $14.5 \mathrm{~g} \mathrm{~m}^{-2} \mathrm{~d}^{-1}$ (Ogden 1977, Scoffin et al. 1980، Bak et al. 1984). These values overlap the $12.5 \mathrm{~g} \mathrm{~m}^{-2} \mathrm{~d}^{-1}$ calculated for the Moorea reef. Highest recorded rates of echinoid reef framework destruction appear to be similar in the IndoPacific and Atlantic.
Do such bioerosion rates have any significance among the forces determining the fate of the reef structure? The main constructive element, in the interplay between construction and destruction, is growth of the living coral colonies (Table 4). Approximately $15 \%$ of the reef bottom at Tiahura is living coral (Table 1), predominantly massive Porites species. Skeletal extension rates of such colonies are $1 \mathrm{~cm} \mathrm{yr}^{-1}$ (Bak \& Laane 1987 ) and skeletal density is about $1.4 \mathrm{~g} \mathrm{~cm}^{-3}$ (Hughes 1987). Consequently, in situ growth of the reef structure approximates $2100 \mathrm{~g} \mathrm{~m}^{-2} \mathrm{yr}^{-1}$ or $6 \mathrm{~g} \mathrm{~m}^{-2} \mathrm{~d}^{-1}$. Other constructive and destructive forces, such as growth of crustose coralline algae or microexcavations, are of a smaller order of magnitude and they will partly counterbalance each other. The conclusion must be that, with a coral growth rate of $6 \mathrm{~g} \mathrm{~m}^{-2} \mathrm{~d}^{-1}$ and a bioerosion rate of $12.5 \mathrm{~g} \mathrm{~m}^{-2} \mathrm{~d}^{-1}$, the hard reef structure at Tiahura is inevitably being changed into a sandy sediment (Table 4 ).

Table 4. Major forces of construction/destruction at Tiahura reef

\begin{tabular}{|c|c|}
\hline \multicolumn{2}{|l|}{ Construction } \\
\hline Cover living coral ${ }^{a}$ & $15 \%$ \\
\hline Linear growth ${ }^{\mathrm{b}}$ & $1 \mathrm{~cm} \mathrm{yr}^{-1}$ \\
\hline Skeletal densityc & $1.4 \mathrm{~g} \mathrm{~cm}^{-3}$ \\
\hline Accumulation reef frame & $2100 \mathrm{~g} \mathrm{~m}^{-2} \mathrm{yr}^{-1}$ \\
\hline \multicolumn{2}{|l|}{ Destruction } \\
\hline Bioerosion Diadema savignyi & $9.2 \mathrm{~g} \mathrm{~m}^{-2} \mathrm{~d}^{-1}$ \\
\hline Bioerosion Echinothrix diadema & $2.2 \mathrm{~g} \mathrm{~m}^{-2} \mathrm{~d}^{-1}$ \\
\hline Bioerosion Echinometra mathaei & $1.0 \mathrm{~g} \mathrm{~m}^{-2} \mathrm{~d}^{-1}$ \\
\hline Total & $12.5 \mathrm{~g} \mathrm{~m}^{-2} \mathrm{~d}^{-1}$ \\
\hline Echinoid bioerosion & $4550 \mathrm{~g} \mathrm{~m}^{-2} \mathrm{yr}^{-1}$ \\
\hline \multicolumn{2}{|l|}{ See Table 1} \\
\hline \multicolumn{2}{|l|}{${ }^{b}$ Bak \& Laane (1987) } \\
\hline${ }^{c}$ Hughes (1987) & \\
\hline
\end{tabular}


At Takapoto the situation is quite different. Significant echinoid bioerosion, indeed occurrence of urchins, is restricted to an extremely small part of the lagoon, viz the close vicinity of lagoonal inlets. The obvious question is: what limits the distribution of the urchins? Differential recruitment and predation are the processes most likely to be involved. In an almost closed atoll such as Takapoto, water exchange between the open ocean and the lagoon is extremely limited, only $15 \%$ of the lagoonal volume being exchanged each year (Salvat \& Richard 1985). Ninety-five percent of the abundant benthos consists of filter feeders - an enormous standing stock of naturally occurring and cultured molluscs (Richard 1985, Intes 1988). The energy requirements of this community are very high, sometimes in excess of supply (Intes 1988). The long residence time of lagoonal water, in combination with the great clearance capacity of the abundant filter-feeding benthos, may restrict recruitment of echinoids to the vicinity of the shallow connections to the open ocean.

There are large differences between bioerosion patterns in the lagoons, but it is obvious that high echinoid densities can be of decisive importance for the balance between construction and destruction of the reef structure. The question remains: are the urchin populations of Moorea, in view of the reported generally low urchin densities of the Indo-Pacific oceanic islands, really atypical? In the Caribbean and east African reefs human influence (e.g. overfishing) may be responsible for increased echinoid densities (Hay 1984, McClanahan \& Muthiga 1988). On the Moorea reef human influence is pronounced and the possibility of a parallel relation between increasing anthropogenic stress on reefs and increased echinoid densities in the Indo-Pacific should be considered.

Acknowledgements. I am indebted to Dr M. Peyrot-Clausade for the invitation to join her 1987 mission to French Polynesia (bioerosion program) and to Dr B. Salvat (Antenne Museum E.P.H.E.) for financial support on Takapoto. Mr H. A. van Egmond (Dept Geology, Free University, Amsterdam) prepared the petrographic sections.

\section{LITERATURE CITED}

Bak, R. P. M. Carpay, M. J. E., de Ruyter van Steveninck, E. (1984). Densities of the sea urchin Diadema antillarum before and after mass mortalities on the coral reefs of Curacao. Mar Ecol. Prog. Ser 17: 105-108

Bak, R. P. M. Laane, R. W. P. M. (1987). Annual blackbands in skeletons of reef corals (Scleractinia). Mar. Ecol. Prog. Ser 38: 169-175

Bak, R. P. M., Povel, G. D. E. (1989). Ecological structure and variation in a range of Indonesian fore-reef slope coral communities. Proc. Sixth Int. Coral Reef Symp. 1988 Townsville 3: 191-196
Birkeland, C. (1984). Ecological interactions between mangroves, sea-grass beds, and coral reefs. UNEP Regional Seas Rep. Stud. 73: 1-26

Birkeland, C. (1989). The influence of echinoderms on coral reef communities. In: Jangoux, M., Lawrence, J. M. (eds.) Echinoderm studies, Vol. 3. Balkema, Rotterdam, p. 1-79

Downing, N., El-Zahr, C. R. (1987). Gut evacuation and filling rates in the rock-boring sea urchin, Echinometra mathaei. Bull. mar. Sci. 41: 579-584

Ebert, T. A. (1975). Growth and mortality of post-larval echinoids. Am. Zool. 15: 755-775

Ebert, T. A. (1982). Longevity, life history, and relative body wall size in sea urchins. Ecol. Monogr. 52: 353-394

Galzin, R., Pointer, J. (1985). Moorea Island, Society Archipelago. Proc. Fifth Int. Coral Reef Congr. Tahiti 1 73-101

Glynn, P. W., Wellington, G. M., Birkeland, C. (1979). Coral reef growth in the Galapagos: limited by sea urchins. Science 203: $47-49$

Hawkins, C. M., Lewis, J. B. (1982). Ecological energetics of the tropical sea urchin Diadema antillarum Philippi in Barbados, West Indies. Estuar. coast. Shelf Sci. 15: 645-669

Hay, M. E. (1984). Patterns of fish and urchin grazing on Caribbean coral reefs: are previous results typical? Ecology 65: $446-454$

Hunter, I. G. (1977). Sediment production by Diadema antillarum on a Barbados fringing reef. Proc. Third Int. Coral Reef Symp. Miami 2: 106-109

Hughes, T P. (1987). Skeletal density and growth form of corals. Mar. Ecol. Prog. Ser. 35; 259-266

Intes, A. (1988). Pearl farming responsible of its own death? Abstract 198, Abstracts Sixth Int. Coral Reef Symp. Townsville 1988 , p. 50

Lessios, H. A., Robertson, D. R., Cubit, J. D. (1984). Spread of Diadema mass mortality through the Caribbean. Science 226: $335-337$

McClanahan, T R., Muthiga, N. A. (1988). Changes in Kenyan coral reef community structure and function due to exploitation. Abstract 267, Abstracts Sixth Int. Coral Reef Symp. Townsville 1988, p. 67

Ogden, J. C. (1977). Carbonate-sediment production by parrot fish and sea urchins on Caribbean reefs. In: Frost, S. H., Weiss, M. P. Saunders, J. B. (ed.) Studies in geology, Vol. 4. Reefs and related carbonates-ecology and sedimentology. Am. Ass. Petrol. Geol. Tulsa, p. 281-288

Ogden, J. C. (1987). Comparison of the tropical western Atlantic (Caribbean) and the Indo-Pacific: Herbivore-plant interactions. UNESCO Rep. mar. Sci. 46: 167-169

Richard, G. (1985). Fauna and flora, a first compendium of french polynesian sea-dwellers. Proc. Fifth Int. Coral Reef Congr Tahiti 1. 412-445

Russo, A. R. (1980). Bioerosion by two rock-boring echinoids (Echinometra mathaei and Echinostrephus aciculatus) on Eniwetak Atoll, Marshall Islands. J. mar. Res. 38: 99-110

Salvat, B., Richard, G. (1985). Takapoto Atoll, Tuamotu Archipelago. Proc. Fifth Int. Coral Reef Congr. Tahiti 1 323-377

Sammarco, P. W. (1987). A comparison of some ecological processes on coral reefs of the Caribbean and the Great Barrier reef. UNESCO Rep. mar Sci. 46: 127-166

Scoffin, T P., Stearn, C. W., Boucher, D., Frydl, P., Hawkins, C. M., Hunter, I. G., MacGeachy, J. K. (1980). Calcium carbonate budget of a fringing reef on the west coast of Barbados. Bull. mar. Sci 30: 475-508

Manuscript first received: January 31, 1990

Revised version accepted: July 3,1990 